\title{
Heavy metals and their general toxicity on plants
}

\section{Darinka Gjorgieva Ackova}

Faculty of Medical Sciences, Goce Delčev University, Štip, R. Macedonia

\section{Article history}

Received: 16 October 2017 Accepted: 21 November 2017

Published: 01 January 2018

(C) Ackova (2018)

Editor

K K Sabu

Publisher

Horizon e-Publishing Group

Correspondence

Darinka Gjorgieva Ackova

\darinka.gorgieva@ugd.edu.mk

\begin{abstract}
Heavy metals are important environmental pollutants, and their toxicity is a serious problem of great concern for environmental, ecological, nutritional and toxicological reasons. Metals can affected long list of physiological and biochemical processes in plants and their toxicity varies with plant species, particular metal, metal concentration and it chemical form. Throughout the world, researches have been conducted extensive investigations to determine the effects of toxic heavy metals on plants. The process is still going on and the need of intensification of the research programmes for better understanding of heavy metal toxicity is evident.
\end{abstract}

\section{Keywords}

heavy metals; plants; toxicity

\section{Citation}

Ackova D G. Heavy metals and their general toxicity on plants. Plant Science Today 2018; 5(1):14-18. doi: https://dx.doi.org/10.14719/pst.2018.5.1.355

\section{Introduction}

According to the definition, a general term "heavy metals" applies to the group of metals and metalloids with atomic density is greater than 4 $\mathrm{g} / \mathrm{cm}^{3}$, or is 5 times or more, greater than water density (1). In this group, lead (Pb), cadmium (Cd), nickel (Ni), cobalt (Co), iron (Fe), zinc (Zn), chromium (Cr), silver (Ag), arsenic (As), and the platinum group elements are included. There is also an alternative classification of metals which is based on their coordination chemistry. This classification categorizes heavy metals as class B metals that are non-essential trace elements and are highly toxic elements such as $\mathrm{Hg}, \mathrm{Ag}, \mathrm{Pb}, \mathrm{Cd}$ and $\mathrm{Ni}$.

Some of the heavy metals are bioaccumulative, they do not breakdown in the environment and they are not easily metabolized, which is the main reason for their accumulation in food chain at primary producers (through the uptake of plants) and at consumer levels (through consumption).

Fast economic development and increasing industrialization world wide cause the release of a wide range of xenobiotics into the atmosphere. Any xenobiotic in the environment, which causes undesirable effects, impair the welfare of the environment, reduce the life quality and eventually cause death of different organisms is named as a pollutant (2). This kind of xenobiotics has to be present in the environment beyond tolerance limit. Hence, heavy metals are important environmental pollutants, and their toxicity is a problem of great concern for environmental, ecological, nutritional and toxicological reasons. Heavy metals are considered as particularly relevant genotoxic agents due to their long term persistence in the environment.

Metals can affected long list of physiological and biochemical processes in plants and their toxicity 


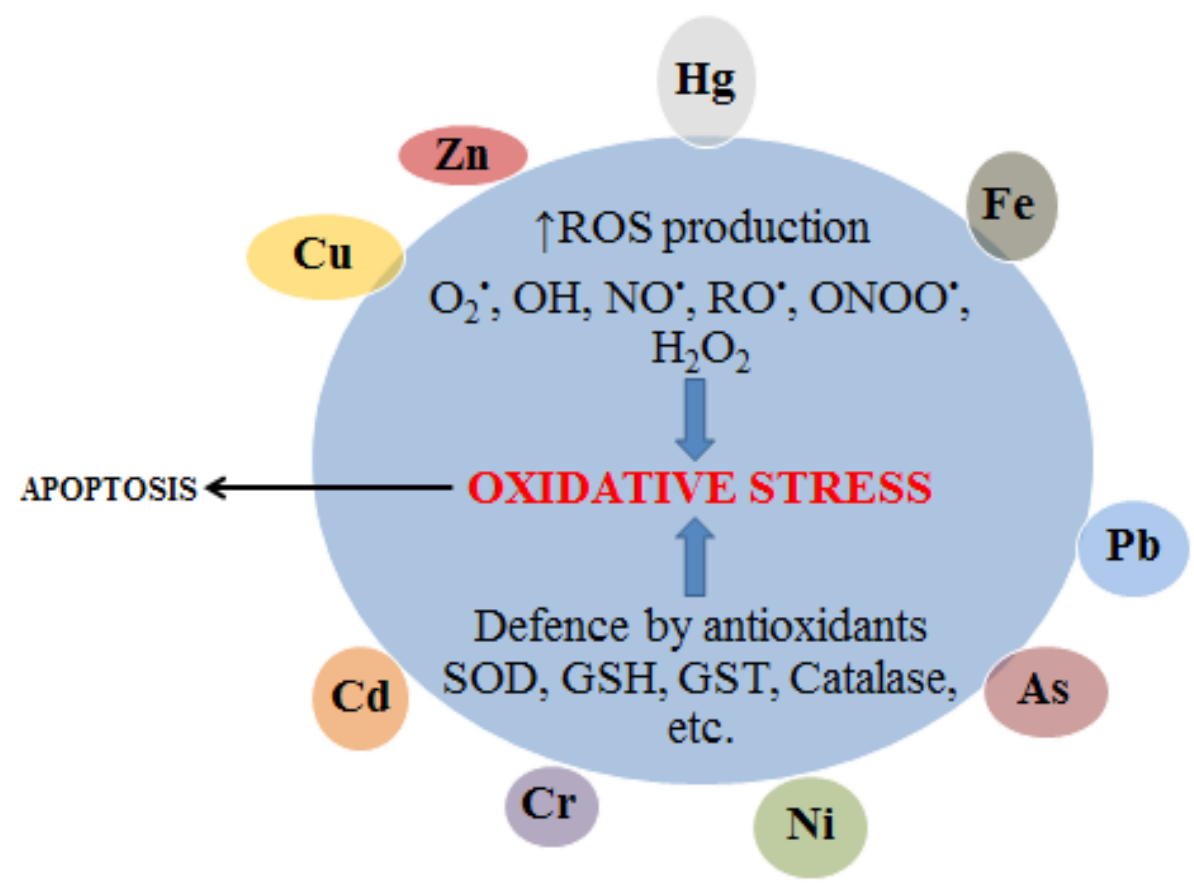

Fig. 1. Effect of heavy metal stress on antioxidant systems in plant cell

varies with plant species, particular metal, metal concentration and its chemical form. As many heavy metals are considered to be essential for plant growth, soil composition and $\mathrm{pH}$ are also importance. Some of the heavy metals, like $\mathrm{Cu}$ and Zn, serves as cofactors and enzyme activators, but others such as $\mathrm{Cd}, \mathrm{Hg}$ and As, are extremely poisonous resulting in growth inhibition and death of organisms which are present at high concentrations. Roots of plants are the initial contact site for heavy metals but they are also absorbed directly to the plant leaves due to the deposition on its surfaces.

Because of the influence of the plant itself and environmental factors, the levels of heavy metals in plants can be widely different $(3,4)$. The data in Table-1 indicates very clear presentation of these findings. The comparison is made between the ranges of heavy metals observed in land plants (2) and regulatory standards for heavy metals in food and drinking water in different countries (5, $6)$.

\section{General toxic effects of heavy metals on plants}

Throughout the world, researches have been conducted extensive investigations to determine the effects of toxic heavy metals on plants (7-18). Plants are sensitive both to the deficiency and sufficiency of some heavy metal ions including essential micronutrients and also strongly poisonous ones. Here, we have reviewed some facts about metal toxicity of selected metals in plants with intention to put point on issue which can have detrimental effects not only on plant itself, but also on human health as consequence.

\section{Cadmium effects on plants}

Cadmium is very toxic element for all living organisms and as far as is known, and is not metabolically involved. Cadmium is an extremely mobile element in the soil, and easily transported through the plant and distributed to all plant organs subsequently (19-21).The normal limits of $\mathrm{Cd}$ contents in plants are stated between 0.2-0.8 $\mathrm{mg} \mathrm{kg}{ }^{-1}$ and toxic concentrations of $\mathrm{Cd}$ are defined as 5-30 $\mathrm{mg} \mathrm{kg}^{-1}(20)$. Depending on their Cd content, plants are classified as $\mathrm{Cd}$ accumulators or $\mathrm{Cd}$ avoiders. Cd interfere with the uptake, transport and use of several elements ( $\mathrm{K}, \mathrm{Ca}, \mathrm{Mg}$, and $\mathrm{P}$ ) by plants and also interact with the water balance (22). Containing high levels of $\mathrm{Cd}$, plants show visible symptoms of toxicity reflected as chlorosis, growth inhibition, browning of roots and leads to death $(18,23-25)$. Cd inhibits enzyme activity in plants, as root Fe (III) reductase (led to Fe (II) deficiency and affect photosynthesis), nitrate reductase activity in the shoots (reduced the absorption of nitrates and its transport), enzymes involved in $\mathrm{CO}_{2}$ fixation, etc.

\section{Lead effects on plants}

Lead $(\mathrm{Pb})$ is a non-essential element which cause phytotoxicity on plants for long time ago, and its adverse effects on morphology, seed germination, seedling growth, photosynthesis, water content, mineral nutrition, and enzymatic activities are confirmed for all plant species (12, 19, 26-31). As a general rule, the effects are more noticeable at high concentrations of $\mathrm{Pb}$ and duration of exposure. The primary toxic effect of $\mathrm{Pb}$ is find in its extensive reaction with sulfhydryl groups which cause inhibition of enzyme activity and its 
Table 1: Ranges of heavy metals content in land plants and regulatory standards for heavy metals in food and drinking water in different countries (Europe, India, Canada \& China)

\begin{tabular}{|c|c|c|c|c|c|c|}
\hline \multirow[t]{2}{*}{ Elements } & \multirow{2}{*}{$\begin{array}{c}\text { Content measured } \\
\text { in different plants } \\
(\mu \mathrm{g} / \mathrm{g} \mathrm{dw})\end{array}$} & \multicolumn{2}{|c|}{ Indian standards } & \multirow{2}{*}{$\begin{array}{c}\text { Canada } \\
\text { (in row herbal } \\
\text { materials) } \\
(\mathrm{mg} / \mathrm{kg})\end{array}$} & \multirow[t]{2}{*}{ WHO (mg/kg) } & \multirow{2}{*}{$\begin{array}{c}\text { China } \\
\text { (herbal material) } \\
(\mathrm{mg} / \mathrm{kg})\end{array}$} \\
\hline & & $\begin{array}{l}\text { Food } \\
\text { (mg/kg) }\end{array}$ & $\begin{array}{l}\text { Water } \\
(\mathrm{mg} / \mathrm{L})\end{array}$ & & & \\
\hline As & $0.02-7$ & 1.1 & 0.05 & 5 & Nil & 2 \\
\hline $\mathrm{Cd}$ & $0.1-2.4$ & 1.5 & 0.01 & 0.3 & 0.3 & 1 \\
\hline $\mathrm{Hg}$ & $0.005-0.02$ & Nil & Nil & 0.2 & Nil & 0.5 \\
\hline $\mathrm{Pb}$ & $1-13$ & 2.5 & 0.1 & 10 & 10 & 10 \\
\hline Co & $0.05-0.5$ & Nil & Nil & Nil & Nil & Nil \\
\hline $\mathrm{Cr}$ & $0.2-1$ & 20 & 0.05 & 2 & Nil & Nil \\
\hline $\mathrm{Cu}$ & 4.15 & 30 & 0.05 & Nil & Nil & Nil \\
\hline $\mathrm{Fe}$ & 140 & Nil & 0.03 & Nil & Nil & Nil \\
\hline Mn & $15-100$ & Nil & 0.1 & Nil & Nil & Nil \\
\hline $\mathrm{Ni}$ & 1 & 1.5 & Nil & Nil & Nil & Nil \\
\hline $\mathrm{Zn}$ & $8-100$ & 50 & 5.0 & Nil & Nil & Nil \\
\hline
\end{tabular}

induction effect on reactive oxygen species (ROS) production which cause oxidative stress $(11,32$, 33).

\section{Arsenic effects on plants}

Arsenic is a non-essential and generally toxic element to plants, which inhibits root extension and proliferation, inhibits biomass production, interfere with metabolic processes (As is an analog of phosphate (P) and competes for the same uptake carriers) and can severely inhibit plant growth by compromising plant reproductive capacity $(34,35)$. The molecular mechanisms of generation of physiological responses to As exposure are not clear. On one side of As toxicity phenomena is fact that plant growth is stimulated at low concentrations of As and on the other side, the plants that are naturally tolerant and hyperaccumulate As (35-39). Arsenic exposure generally induces the production of reactive oxygen species (ROS) that can lead to oxidative stress. The binding of As (III) to proteins can have profound effects on their folding. Among proteins that are known to bind As (III) are transcription factors, signal transduction proteins, metabolic enzymes, redox regulatory enzymes, and structural proteins (40, 41).

\section{Zinc effects on plants}

Zinc is an essential element for all living organisms and plays an important role in the biosynthesis of enzymes, auxins and other proteins on plants. The range of 300-400 $\mathrm{mg} \mathrm{kg}^{-1} \mathrm{dw}$ is accepted as toxicity limit for $\mathrm{Zn}$ in plants, but there are variations according plant species and growth stage (20). Generally, $\mathrm{Zn}$ is not considered to be highly phytotoxic metal, but contents of Zn found in surrounding contaminated soils frequently exceed the required as nutrients and may cause phytotoxicity. The main signs of $\mathrm{Zn}$ toxicity in various plant species (which is also relevance for Cd phytotoxicity) are indicated by decrease in growth (both roots and shoots) and development of the plant, alteration in metabolism processes and induction of oxidative damage (18, 31, 42-45). Zinc toxicity also causes chlorosis, at beginning of exposure in the younger leaves, and after prolonged exposure, chlorosis is extended to older leaves also (46).

\section{Effects of heavy metals on antioxidant activity in plants}

Besides the fact that antioxidant systems composed of antioxidants and specific enzymes, are being studied extensively, still some important intrinsic mechanisms and characteristics about this network remain unknown (47-50). The stress that heavy metals have on antioxidant system and plant cell is presented on Fig. 1. The main toxic effects of heavy metals over antioxidant system are seen in the increase in activity of some enzymes, depletion of depot of low molecular weight antioxidants and generation of ROS. There is a variety of studies in various plant species subjected to heavy metal stress that reported the antioxidant activity effects on plants $(2,17,51,52)$. Heavy metals can interfere with the antioxidants level in plants, can reduce the nutritive value, and because dietary intake of heavy metals through consumption of plants is not negligible and can have detrimental effects on human health. 


\section{Conclusion}

Heavy metals and their toxicity on plants and other living organisms are present above certain limits are in focus of the researches long time ago. The importance of this topic is evidences by the fact that the process is still going on. The need of intensification of the research programmes for better understanding of heavy metal toxicity is evident, and this goal must be reached if final effect for improving the welfare of biosphere is wanted.

\section{Conflict of interest}

The author declare that have no competing interests.

\section{References}

1. Hawkes SJ. What is a "Heavy metal"? J Chem Edu. 1997; 74:1369-74. http://pubs.acs.org/doi/abs/10.1021/ed074p1374

2. Nagajyoti PC, Lee KD, Sreekanth TVM. Heavy metals, occurrence and toxicity for plants: a review. Environ Chem Lett. 2010; 8:199-216. https://doi.org/10.1007/s10311-010-0297-8

3. Wong JWC. Heavy metal contents in vegetables and marketgarden soils in Hong Kong. Environ Technol. 1996; 17:407-14. https://doi.org/10.1080/09593331708616400

4. Gjorgieva D, Kadifkova-Panovska T, Bačeva K, Stafilov T. Assessment of Heavy Metal Pollution in R. Macedonia Using a Plant Assay. Arch Environ Contam Toxicol. 2011; 60: 233-40. http://doi: 10.1007/s00244-010-9543-0

5. Awashthi SK. Prevention of Food Adulteration Act no 37 of 1954. Central and State Rules as Amended for 1999. Ashoka Law House, New Delhi. 2000.

6. WHO. WHO guidelines for assessing quality of herbal medicines with reference to contaminants and residues. WHO, 2007. http://apps.who.int/medicinedocs/documents/s1 4878e/s14878e.pdf

7. Peralta JR, Gardea-Torresdey JL, Tiemann KJ, Gomez E, Arteaga S, Rascon E, Parsons JG. Uptake and effects of five heavy metals on seed germination and plant growth in alfa alfa (Medicago sativa L.). Bull Environ Contam Toxicol. 2001; 66:727-34. https://doi.org/10.1007/s001280069

8. Cook CM, Sgardelis SP, Pantis JD, Lanaras T. Concentrations of $\mathrm{Pb}, \mathrm{Zn}$ and $\mathrm{Cu}$ in Taraxacum spp. in relation to urban pollution. Bull Environ Contam Toxicol. 1994; 53:204-10. https://doi.org/10.1007/BF00192034

9. Reeves RD, Baker AJM. Metal-accumulating plants. In: Raskin I, Ensley BD, editors. Phytoremediation of toxic metals: using plants to clean up the environment. Wiley, New York; 2000. p. 193-229.

10. Hagemeyer J. Ecophysiology of plant growth under heavy metal stress. In Prasad MNV, editor. Heavy metal stress in plants: From molecules to ecosystems. $2^{\text {nd }}$ ed. Berlin: Springer; 2004. p.201-22.
11. Sharma P, Dubey RS. Lead toxicity in plants Braz J Plant Physiol. 2005; 17:35-52. https://doi.org/10.1590/S1677-04202005000100004

12. An Y-J. Assessment of comparative toxicities of lead and copper using plant assay. Chemosphere 2006; 62:1359-65. https://doi.org/10.1016/j.chemosphere.2005.07.044

13. Calzoni GL, Antognoni F, Pari E, Fonti P, Gnes A, Speranza A. Active biomonitoring of heavy metal pollution using Rosa rugosa plants. Environ Poll. 2007; 149:239-45. https://doi.org/10.1016/j.envpol.2006.12.023

14. Barandovski L, Cekova M, Frontasyeva MV, Pavlov SS, Stafilov T, Steinnes E, Urumov V. Atmospheric deposition of trace element pollutants in Macedonia studied by the moss biomonitoring technique. Environ Monitor Assess. 2008; 138:107-18. https://doi.org/10.1007/s10661-007-9747-6

15. Güleryüz G, Arslan H, Çelik C, Gücer Ş, Kendall M. Heavy metal content of plant species along Nilűfer stream in industrialized Bursa City, Turkey. Water Air Soil Pollut. 2008; 195: 275-84. https://doi.org/10.1007/s11270-008-9745-5

16. Warne MS, Heemsbergen D, Stevens D, McLaughlin M, Cozens G, Whatmuff M, Broos K, Barry G, Bell M, Nash D, Pritchard D, Penney N. Modeling the toxicity of copper and zinc salts to wheat in 14 soils. Environ Toxicol Chem. 2008; 27:786-92. https://doi.org/10.1897/07-294.1

17. Gjorgieva D, Kadifkova Panovska T, Ruskovska T, Bačeva K, Stafilov T. Mineral nutrient imbalance, total antioxidants level and DNA damage in common bean (Phaseolus vulgaris L.) exposed to heavy metals. Physiol Mol Biol Plants. 2013B; 19: 499-507. https://doi.org/10.1007/s12298-013-0196-0

18. Versieren L, Evers S, AbdElgawag H, Asard H, Smolders E. Mixture toxicity of copper, cadmium, and zinc to barley seedlings is not explained by antioxidant and oxidative stress biomarkers. Environ Toxicol Chem. 2017; 36: 220-30. https://doi.org/10.1002/etc.3529

19. Gruenhage L, Jager IIJ. Effect of heavy metals on growth and heavy metals content of Allium porrum and Pisum sativum. Angew Bot. 1985; 59:11-28.

20. Kabata-Pendias A, Pendias H, editors. Trace elements in soils and plants. $2^{\text {nd }}$ ed.Boca Raton, Florida, USA: CRC Press Inc; 1992.

21. Schulze E-D, Beck E, Muller-Hohenstein K. Plant Ecology. Berlin-Heidelberg: Springer; 2005.

22. Das P, Samantaray S, Rout GR. Studies on cadmium toxicity inplants: a review. Environ Pollut.1997; 98:29-36.

23. Mohanpuria P, Rana NK, Yadav SK. Cadmium induce doxidative stress influence on glutathione metabolic genes of Camella sinensis (L.) O. Kuntze. Environ Toxicol. 2007; 22:368-74. https://doi.org/10.1002/tox.20273

24. Pandey N, Sharma CP. Effect of heavy metals $\mathrm{Co}^{2+}, \mathrm{Ni}^{2+}$, and $\mathrm{Cd}^{2+}$ on growth and metabolism of cabbage. Plant Sci. 2002; 163:753-58. https://doi.org/10.1016/S0168-9452(02)00210-8

25. Guo J, Dai X, Xu W, Ma M. Over expressing GSHI and As PCSI simultaneously increases the tolerance and accumulation of cadmium and 
arsenic in Arabidopsis thaliana. Chemosphere 2008;72:1020-26.

https://doi.org/10.1016/j.chemosphere.2008.04.018

26. Miller JE, Hassete JJ, Koppe DE. Interaction of lead and cadmium of electron energy transfer reaction in corn mitochondria. Physiol Plant.1973; 28:166-71. https://doi.org/10.1111/j.1399-3054.1973.tb01170.x

27. Morzck EJr, Funicclli NA. Effect of lead and on germination of Spartina alterniflora loisel seeds at various salinities. Environ Exp Bot.1982; 22:23-32. $\quad$ https://doi.org/10.1016/00988472(82)90005-3

28. Van Assche F, Clijsters H. Effects of metals on enzyme activity in plants. Plant Cell Environ.1990; 13:195-206. https://doi.org/10.1111/j.1365-3040.1990.tb01304.x

29. Kumar G, Singh RP, Sushila. Nitrate assimilation and biomass production in Seasamum indicum (L.) seedlings in a lead enriched environment. Wat Air Soil Poll.1993; 66:163-71. https://doi.org/10.1007/BF00477067

30. Kupper H, Kupper F, Spiller M. Environmental relevance of heavy metal-substituted chlorophylls using the example of water plants. J Exp Bot. 1996; 47:259-66. https://doi.org/10.1093/jxb/47.2.259

31. Chen Q, Zhang X, Liu Y, Wei J, Shen W, Shen Z, Cui J. Hemin-mediated alleviation of zinc, lead and chromium toxicity is associated with elevated photosynthesis, antioxidative capacity; suppressed metal uptake and oxidative stress in rice seedlings. Plant Growth Regul. 2017; 81:25364. https://doi.org/10.1007/s10725-016-0202-y

32. Patra M, Bhowmik N, Bandopadhyay B, Sharma A. Comparison of mercury, lead and arsenic with respect to genotoxic effects on plant systems and the development of genetic tolerance. Environ Exp Bot. 2004; 52:199-223. https://doi.org/10.1016/j.envexpbot.2004.02.009

33. Reddy AM, Kumar SG, Jyotsnakumari G, Thimmanayak S, SudhakarC. Lead induced changes in antioxidant metabolism of horsegram (Macrotyloma uniflorum (Lam.) Verdc.) and bengalgram (Cicer arietinum L.). Chemosphere 2005; 60:97-104. https://doi.org/10.1016/j.chemosphere.2004.11.092

34. Meharg AA, Macnair MR. Suppression of the high affinity phosphate uptake system; a mechanism of arsenate tolerance in Holcus lanatus L. J Exp Bot. 1992; 43:519-24. https://doi.org/10.1093/jxb/43.4.519

35. Garg N, Singla P. Arsenic toxicity in crop plants: physiological effects and tolerance mechanisms. Environ Chem Lett. 2011; 9: 303-21. https://doi.org/10.1007/s10311-011-0313-7

36. Miteva E. Accumulation and effect of arsenic on tomatoes. Commun Soil Sci Plant Anal. 2002; 33:1917-26. https://doi.org/10.1081/CSS-120004832

37. Pickering IJ, Gumaelius L, Harris HH, Prince RC, Hirsch G, Banks JA, Salt DE, George GN. Localizing the biochemical transformations of arsenate in a hyper accumulating fern. Environ Sci Technol. 2006; 40: 5010-14. https://doi.org/10.1021/es052559a

38. Zhao FJ, Ma JF, Meharg AA, McGrath SP. Arsenic uptake and metabolism in plants. New Phytol.
2009; 181: 777-94. https://doi.org/10.1111/j.14698137.2008.02716.x

39. Finnegan PM, Chen W. Arsenic toxicity: the effects on plant metabolism. Frontiers in Physiology/Plant Physiology. 2012; vol. 3: article 182. https://doi.org/10.3389 /fphys.2012.00182

40. Cline DJ, Thorpe C, Schneider JP. Effects of As(III) binding on alpha-helical structure. J Am Chem Soc. 2003; 125:2923-29. https://doi.org/10.1021/ja0282644

41. Ramadan D, Cline DJ, Bai S, Thorpe C, Schneider JP. Effects of As(III) binding on $\beta$-hairpin structure. J Am ChemSoc. 2007; 129:2981-88. https://doi.org/10.1021/ja067068k

42. Cakmak I, Marshner H. Effect of zinc nutritional status on superoxide radical and hydrogen peroxide scavenging enzymes in bean leaves. In: Barrow NJ, editor. Plant nutrition-from genetic engineering field practice. Netherlanad: Kluwer; 1993. p. 133-37.

43. Fontes RLS, Cox FR. Zinc toxicity in soybean grown at high iron concentration in nutrient solution. J Plant Nutri.1998; 21:1723-30. https://doi.org/10.1080/01904169809365517

44. Prasad KVSK, Pardha Saradhi P, Sharmila P. Concerted action of antioxidant enzyme and curtailed growth under zinc toxicity in Brassica juncea. Environ Exp Bot. 1999; 42:1-10. https://doi.org/10.1016/S0098-8472(99)00013-1

45. Busher AS, Schenk MK. Toxicity level for phytoavailable zinc in compost peat substrates. Sci Hortic, Amsterdam. 2000; 83:339-52. https://doi.org/10.1016/S0304-4238(99)00086-2

46. Ebbs SD, Kochian LV. Toxicity of zinc and copper to Brassica species: implications for phytoremediation. J Environ Qual. 1997; 26:77681. $00472425002600030026 x$ https://doi.org/10.2134/jeq1997.

47. Dietz KJ, Baier M, Kramer U. Free radicals and reactive oxygen species as mediators of heavy metal toxicity in plants. In: Heavy metal stress in plants. Springer, Berlin, Heidelberg. 1999.

48. Michalak A. Phenolic compounds and their antioxidant activity in plants growing under heavy metal stress. Pol J Environ Stud. 2006; 15: 523-30.

49. Singh R, Gautam N, Mishra A, Gupta R. Heavy metals and living systems: an overview. Indian J Pharmacol. 2011; 43: 246-53. https://doi.org/10.4103/0253-7613.81505

50. Jaishankar M, Tseten T, Anbalagan N, Mathew $\mathrm{BB}$, Beeregowda KN. Toxicity, mechanism and health effects of some heavy metals. Interdiscip Toxicol. 2014; 7: 60-72. https://doi.org/10.2478/intox-2014-0009

51. Gjorgieva D, KadifkovaPanovska T, Ruskovska T, Bačeva K, Stafilov T. Influence of heavy metal stress on antioxidant status and DNA damage in Urtica dioica. BioMed Research International (subject Toxicology) 2013a; Volume 2013: Article ID 276417. https://doi.org/10.1155/2013/276417

52. Pérez Alvarez S, Sida-Arrerola JP, Chávez ES, Ardisana EFH. Expression analysis and biochemical characterization of beans plants biofortificated with zinc. Saudi J Biol Sci. 2017; 24:1322-26. https://doi.org/10.1016/j.sjbs.2016.12.014 